\title{
ORIGIN OF POTHOLES IN GLACIATED REGIONS
}

\author{
By C. G. Higgins \\ (University of California, Davis, California, U.S.A.)
}

\begin{abstract}
A review of the inadequacies of the glacial moulin hypothesis for the origin of potholes.
RÉsumé. Une critique des insuffisances de l'hypothèse des moulins glaciaires pour expliquer la provenance des marmites de géant.
\end{abstract}

FIRST proposed by Charpentier ${ }^{1}$ and later popularized by Brögger and Reusch ${ }^{2}$, the glacial moulin explanation for the origin of large potholes was widely and, for the most part, uncritically accepted for almost a century. In the early 1930's several writers 3,4 began to doubt the moulin hypothesis and by the early I950's most writers had abandoned it in favor of the view that large potholes are formed by eddy currents in sub-aerial or subglacial streams. However, a vigorous

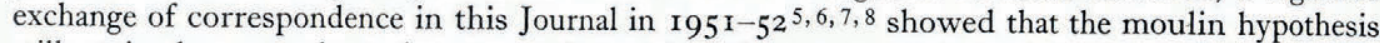
still retained some ardent advocates and provoked the present review of the subject.

Briefly, the moulin hypothesis holds that certain deep, cylindrical bedrock cavities, or "potholes"*, were eroded by melt water torrents plunging vertically down through glacial crevasses or "moulins" $\dagger$ to the glacier bed, thence flowing away as subglacial streams. Traditionally, the hypothesis concerns only erosive effects at the base of the waterfall and disregards any effects of the resultant subglacial stream.

Early writers recognized that potholes are formed in modern sub-aerial streams and that "these differ in appearance from moulin-formed potholes only in that the latter lack flaring edges and stream-worn bedrock surfaces between them"9. Thus committed to emphasizing the differences between stream-worn and supposedly moulin-formed potholes, and already predisposed to finding different origins for them, these writers neglected stream potholes and concentrated their attention on alleged moulin potholes in efforts to find features that would confirm the moulin hypothesis. As a result, they failed to recognize that many of the features they cited as being unique with moulin potholes are also characteristic of many stream-worn potholes:
gigantic size ("giant's kettles")
large boulders, supposedly "grinders", in the potholes
lack of flaring edges
spiral flutes and grooves on the walls
half-potholes.

The recent, excellent observations on modern stream-worn potholes by Ängeby 10, 11 and others show clearly that these features cannot be cited as evidence for moulin origin. On the contrary, according to the principle of Uniformitarianism, they suggest formation by running water.

The remaining " unique" features of supposed moulin potholes :
occurrence in glaciated areas
occurrence on hillslopes or hilltops, high above modern drainage
rapids) might be expected to have formed
glacial striae and polish on intervening bedrock surfaces
potholes filled with glacial till

occurrence in clusters on convex slopes where glacial crevasses (or subglacial stream

\footnotetext{
* Authors have called such features "potholes", "pot-holes" and "pot holes". The latter term is also used synonymously with "swallow holes" in reference to solutional "sink-holes" in limestone, and all three terms have been applied to several other sorts of bedrock depressions. In a now comic exchange of correspondence in Science, Vol. 10, 1899 , several writers (O. H. Hershey, p. 58; F. F. Hilder, p. 88; O. C. Farrington, p. 187; and G. P. Merrill, p. 298) solemnly debated whether the term "pot-hole" was offensive to good taste and should be replaced by the Spanish word, "remolino". Large potholes have been called "giant's kettles (or cauldrons)" in various languages: "marmites de géant", "Riesentöpfe (-kessel)", "jättegrytor", etc. (The spelling of the word pothole appears to have varied on both sides of the Atlantic. Earlier U.S. writers favored "pot-hole" - the spelling in Great Britain - but recent ones have used "pothole" rather
consistently.) consistently.)

† Some writers (e.g., Gilbert, G. K., ref. 14, p. 317-20) have restricted the term "moulin" to the waterfall itself or even to the waterfall erosion process. Some others have used it broadly to include any crevasse, whether or not enlarged
by ablation, occupied by a waterfall.
} 
do not, in themselves, 'show that the holes were bored by englacial waterfalls, but only that the potholes were formed during (or before) glaciation. The same features would be expected to be associated with potholes that were formed as normal eddy-holes by subglacial or latero-glacial streams.

There is no direct evidence that moulin waterfalls form potholes. Neither is there, as noted above, any indirect evidence that they might have done so. Furthermore, there are grave mechanical difficulties in the moulin hypothesis. In addition to minor objections, "the main objection to the hypothesis lies in the difficulty of conceiving the moulin as existing long enough in the necessary definite form at the same spot, or as reforming in the same manner and at the same spot often enough to account for the work accomplished"12. After discussing this difficulty thoroughly, Alexander concluded that it was insurmountable ${ }^{13}$.

However, even if moulin torrents could remain long enough in one spot to erode the bedrock, it is doubtful that they could produce the deep, cylindrical potholes ascribed to them. Gilbert noted that these require "whirling water. Mere impact of the plunging water is not sufficient if there is no enclosure or obstruction to determine a whirl" 14 . Alexander's hydraulic experiments confirmed this.

Alexander concluded that deep, spirally-grooved potholes are formed only when the incoming water jet enters the pothole obliquely at a low angle and spirals down the walls, rotates the scouring tools at the bottom, and exits up the center*. He found that a high-angle or vertical jet plunges down the center to the bottom of the hole, fans out along the bottom and exits radially upward along the walls, eroding a broad, flaring plunge-pool depression.

Conditions necessary to produce oblique deflection of a moulin torrent at the bottom of a moulin must be comparatively rare, so that only a correspondingly small proportion of moulin-formed potholes would be of the deep, cylindrical, eddy-hole type; the majority would be flaring basins of the plunge-pool type. However, in the classic areas of supposed moulin erosion, deep potholes predominate just as exactly similar potholes predominate where modern, vigorous streams flow over bedrock obstructions.

In short, there is neither direct nor indirect evidence that moulin action forms potholes. Furthermore, in the unlikely event that moulin torrents could remain long enough or often enough at one spot, they would actually produce potholes quite different from those that have been ascribed to them. On the other hand, all features of potholes ascribed to moulin erosion may readily be explained as natural consequences of erosion by sub-, en-, or latero-glacial streams, as has been so ably demonstrated by Ängeby and Alexander. In view of these arguments, continued entertainment of the moulin hypothesis seems a needless extravagance.

\section{MS. received 8 February 1956}

* Ängeby (ref. ro, p. 25), in an experiment with an actual spirally-grooved pothole $7 \cdot 9 \mathrm{~m}$. deep, confirmed Alexander's laboratory observations on spiral flow. Alexander found no basis for the contention of Brögger and Reusch, op. cit., p. 765 (cf. Streiff-Becker, ref. 7) that a high-angle jet produces spiral flow passing upward against the walls.

\section{R E F E RE N C E S}

1. Charpentier, Jean de. Essai sur les glaciers et sur le terrain erratique du bassin du Rhône. Lausanne, Marc Ducloux, I 84 I. $363 \mathrm{p}$.

2. Brögger, W. C., and Reusch, H. H. Giant's kettles at Christiana. Quarterly fournal Geological Society, Vol. 30,1874 , p. $75^{8}-71$. See Angeby's bibliography (ref. ro) for Danish and German editions of this paper.

3. Geer de, Gerard. Stockholmstraktens kvartärgeologi. Sveriges Geologiska Undersökning, Avhandlirgar och Uppsatser, Ser. Ba, No. I2, I932, p. 2 I.

4. Alexander, H. S. Pothole erosion. Fournal of Geology, Vol. 40, 1932, p. 305-37.

5. Streiff-Becker, R. Pot-holes and glacier mills. Fournal of Glaciology, Vol. I, No. 9, 195 I, p. 488-90.

5. Hollingworth, S. E. Pot-holes and glacier mills; some comments on Dr. Streiff-Becker's article. Fournal of Glaciology, Vol. I, No. 9, 195 I, p. 490.

7. Streiff-Becker, R. Letter in Fournal of Glaciology, Vol. 1, No. 10, r95 1, p. 582.

8. Fægri, Knut. On the origin of pot-holes. Fournal of Glaciology, Vol. 2, No. I I, 1952, p. $24-25$.

9. Upham, Warren. Giant's kettles eroded by moulin torrents. Bulletin, Geological Society of America, Vol. 12, 1900, p. $25-44$.

10. Ängeby, O. Pothole erosion in recent waterfalls. Lund Studies in Geography, Ser. A, No. 2, 1951, p. I-34. [English summary of a longer paper, "Evorsionen i recenta vattenfall," Lund, I95I.]

I I. - Recent, subglacial and lateroglacial pothole-erosion (evorsion). Lund Studies in Geography, Ser. A, No. 3 , 1952 , p. 14-24.

12. Alexander, H. S. op. cit., p. 310

13. Gilbert, G. K. Moulin work under glaciers. Bulletin of the Geographical Society of America, Vol. 17, 1906, p. 3 19. 